\title{
Fertility status of soil along the water course of selected distributory-14 of Shahapur branch canal of UKP command area in Yadgir district of Karnataka
}

\section{CHANDRAGOUDA GIRIGOUDAR, H. V. RUDRAMURTHY AND N. L. RAJESH}

Received : 08.02.2017; Revised : 24.04.2017; Accepted : 06.05.2017

\section{MEMBERS OF RESEARCH FORUM:}

Corresponding author : H. V. RUDRAMURTHY, Department of Soil Science and Agricultural Chemistry, College of Agriculture (U.A.S.) Bheemarayanagudi, YADAGIR (KARNATAKA) INDIA Email: girigoudar1991@gmail.com

Co-authors : CHANDRAGOUDA GIRIGOUDAR AND N. L. RAJESH, Department of Soil Science and Agricultural Chemistry, College of Agriculture, RAICHUR, (KARNATAKA) INDIA

\section{Summary}

The survey work was carried out during the year 2014-15 at Shahapur branch canal of Yadgir district, Karnataka and studied the fertility status of soil along the water course of canal command area. Available nitrogen content was comparatively more in sub surface soils than in surface soils all along the water course of distributory-14. Available phosphorus status in soils at the tail reach was comparatively more than that of head reach. Irrespective of surface and sub surface soils available potassium status was medium and was comparatively low in sub surface than in surface soils. However, increasing trend of potassium from head to tail via middle reach along the water course was observed. Available sulphur status was medium in surface and low in sub surface soils all along the water course. Available nitrogen, phosphorus, potassium and sulphur were strongly correlated with organic carbon $(0.950,0.989,0.986$ and $0.989)$, CEC (-0.841, $-0.895,-0.934$ and -0.946$)$ and dehydrogenase activity $(0.934,0.979,0.980$ and 0.982). Higher concentration of DTPA extractable micronutrients namely, $\mathrm{Fe}, \mathrm{Cu}$ and $\mathrm{Zn}$ in surface than in sub surface soils was observed all along the water course. However, fertility status of soils along the water course was low with respect to both available $\mathrm{N}$ and $\mathrm{P}$, medium with respect to available $\mathrm{K}, \mathrm{S}, \mathrm{Fe}$ and $\mathrm{Zn}$ while high with respect to available $\mathrm{Cu}$ and $\mathrm{Mn}$.

Key words : : Available macro, Micro nutrients, Organic carbon, Dehydrogenase activity

How to cite this article : Girigoudar, Chandragouda, Rudramurthy, H.V. and Rajesh, N.L. (2017). Fertility status of soil along the water course of selected distributory-14 of Shahapur branch canal of UKP command area in Yadgir district of Karnataka . Asian J. Soil Sci., 12 (1) : 108-115 : DOI : 10.15740/ HAS/AJSS/12.1/108-115. 